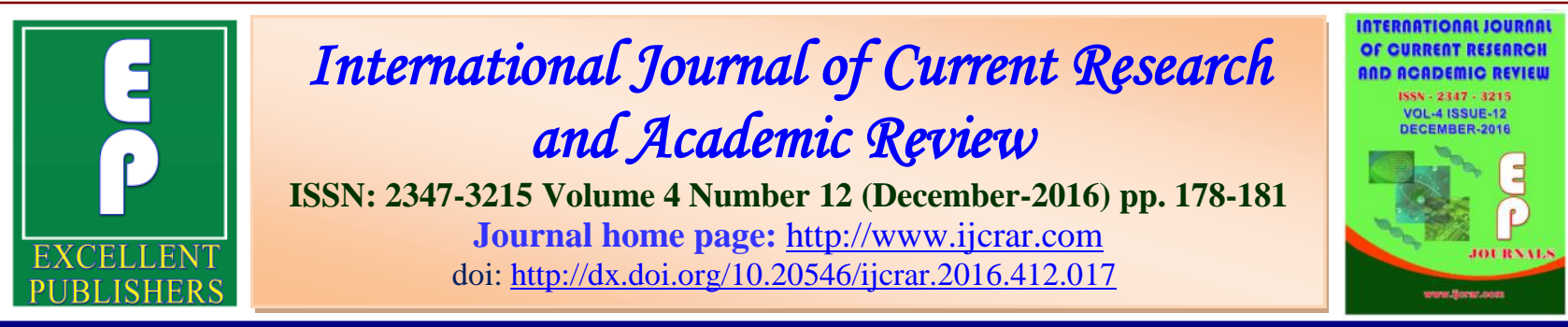

\title{
Sida tiagii Bhandari (Malvaceae) - New Record to the Flora of Maharashtra State and It's Range Extension in Central and Western India
}

\author{
Santosh S. Bhosale ${ }^{1}$, Nandkishor More ${ }^{2}$, Brijkishor M. Rathor ${ }^{1}$ and Arvind S. Dhabe ${ }^{2}$ \\ ${ }^{1}$ Department of Botany, Jaysingpur College, Jaysingpur, Dist. Kolhapur, (M.S) India-416101 \\ ${ }^{2}$ Department of Botany, Dr. Babasaheb Ambedkar Marathwada University Aurangabad \\ (M. S.), India-431004
}

*Corresponding author

\begin{tabular}{l|l}
\hline \multirow{2}{*}{ KEYWORDS } & A B S T R A C T \\
\cline { 2 - 2 } $\begin{array}{l}\text { Sida tiagii, } \\
\text { Bhandari, }\end{array}$ & $\begin{array}{l}\text { Present paper deals with a new record to the Flora of Maharashtra state and } \\
\text { its range extension in Western India. Sida tiagii Bhandari belong to family } \\
\text { Central and }\end{array}$ \\
$\begin{array}{l}\text { Malvaceae is a taxon growing in few localities of Marathwada region of } \\
\text { Maharashtra state and it is found to be rare in distribution and is not reported } \\
\text { in the flora of Maharashtra state earlier. This taxon also extends its range of } \\
\text { distribution from Rajasthan to Maharashtra, India. }\end{array}$
\end{tabular}

\section{Introduction}

Sida L. comprising herbs and subshrubs belongs to the family Malvaceae. The genus comprise about 150 species is found in tropical and subtropical regions of the world (Mabberly, 2008). Bhandhari (1978) reported 7 species of Sida from Indian desert. Singh (1987) reported 8 species of Sida from Rajasthan and Paul (1993) reported 12 species from India. Sivarajan and Pradip (1996) have critically studied the genus in their work on Mavaceae of Southern Peninsular India 15 species and a variety. Cook (1901) in his work reported the occurrence of 6 species and 2 infraspecific taxa. Joshi et al., (2012) reported $S$. tiagii in his Kaccha Island in Gujrat state and recently Tiwari and Shukla (2014) have reported this taxon from Madhya Pradesh.

\section{Methodology}

During our field exploration, many taxa of Sida were collected from various localities of Marathwada region of Maharashtra State. Specimens were brought to the laboratory and processed for herbarium specimens with standard procedure given by Survase and Dhabe (2013). Majority of the Specimens were satisfactorily identified and confirmed by using pertinent literature and voucher specimens were deposited in Herbarium, Department of Botany, Dr. Babasaheb Ambedkar Marathwada University, Aurangabad (BAMU). After critical investigations, authors found that one of the taxon belongs to Sida tiagii Bhandari which 
is a new record to the Flora of Maharashtra. This species is allied to $S$. ovata but differs in its mericarps with completely enclosing calyx and spiny outgrowths just below the awns.

So far this taxon is known to be endemic to Rajasthan and Gujrat (India) and Pakistan. In recent exploration, few more localities were found in Western India in addition to the type localities. This taxon is found to be extended its distributional range from Rajasthan to Madhya Pradesh to the central India and towards Maharashtra in Western India. Therefore, in present paper correct and updated citation, detail description, distributional map showing range of extension, note on its phenology depicted for taxon followed by a note on ecology and taxonomic identity.

Sida tiagii Bhandari in Annals Arid Zone 16: 455. 1977 et Fl. Ind. Desert 74. 1978. S. pakistanica Abedin in Pak. Journ. Bot. 11: 54.1979. V. Singh et al Fl. of Rajasthan 133. 1987. Paul in Shama et al., in Fl. of India 3: 372. 1993.

Much branched, perennial undershrub, densely stellately -tomentose all over. Stem woody at the base. Leaves $1.5-3 \mathrm{~cm} \times 1-1.5$ $\mathrm{cm}$, ovate-oblong to obovate, rounded, entire, 3-5 nerved from base, dentate above, rounded at apex, both surfaces stellately hairy, petioles 1-1.5 cm long, stellate. Pedicels solitary, 3-13 mm long, jointed just below the calyx. Calyx 8-9 $\mathrm{mm}$ long, densely stellate, lobes mucronate enlarged in fruit. Corolla pale-yellow, $1.8 \mathrm{~cm}$ when fully open, petals obliquely obovoid. Staminal tube hirsute. Capsule pentangularovoid, $9 \mathrm{~mm}$ in diam., completely covered by persistant calyx; mericarps 7-8, woody, much reticulated on sides, apex hirsute, 2awned, with 2 glands and 2 spiny outgrowths just below the awns ; awns 5.5 $\mathrm{mm}$ long, hirsute. Seeds $2.5 \mathrm{~mm}$ long, black, glabrous with tufts of stellate hairs at hilum.

Flowering and fruiting: August to October.

Distribution: Pakistan, India- Rajasthan, Gujrat and now Maharashtra.

Lectotype: India, Rajasthan, Barmer Dist. Mungaria, 28 ${ }^{\text {th }}$ August 1962, Bhandari M. M. 1570A (CAL).

Illus: Bhandari M. M. Fl. of Ind. Desert 74. 1978, T. K. Paul in Sharma et al., op.cit. Fl. of India Vol. 3: 295. 1993.

Ecological Note: The taxon occurs in rocky soil and admist grasses and is known only from few collections in Aurangabad, Maharashtra so far, seems to be rare and hence it needs urgent steps towards conservation.

\section{Voucher specimens referred}

Pakistan-Sargodha Dist: Khatwari on way to Naushera, M. Qaiser 2633 (KUH); Jhelum Dist.: Mustafaabad, near Choa Saidan Shah, M.Qaiser \& A. Ghafoor 4569 (KUH) ; Bela Dist.: Sonmiani, S. Abedin \& S. I. Ali 693 (KUH); Dadu Dist.: near Thana Bula Khan, stony hills, S.M.H. Jafri 3699 (KUH); Karachi Dist.: stony hillock, Manghopir, S.M.H. Jafri 1510 (KUH); Thatta Dist: Hazarat Abdullah Shah Mazar, Thatta, S.Abedin 5583 (KUH) Tharparker Dist.: Top Mallah, Virawa, Nagar-parker Road, M. Qaiser 4149 (KUH). India- RajasthanJodhpur: Massuria, foot hills Bhandari M. M. 33, 13. 08. 1959, Barmer: Mungaria, on sand near Gadra Road, 28. 08. 1962, Bhandari M. M. 1570, 1602, Jaisalmer: Amarsagar, Blatter 5628. Gujarat- Kachha Island, Joshi P. N. s.n. Madhya Pradesh- Tiwari A. P. and Shukla A. N. s. n. 

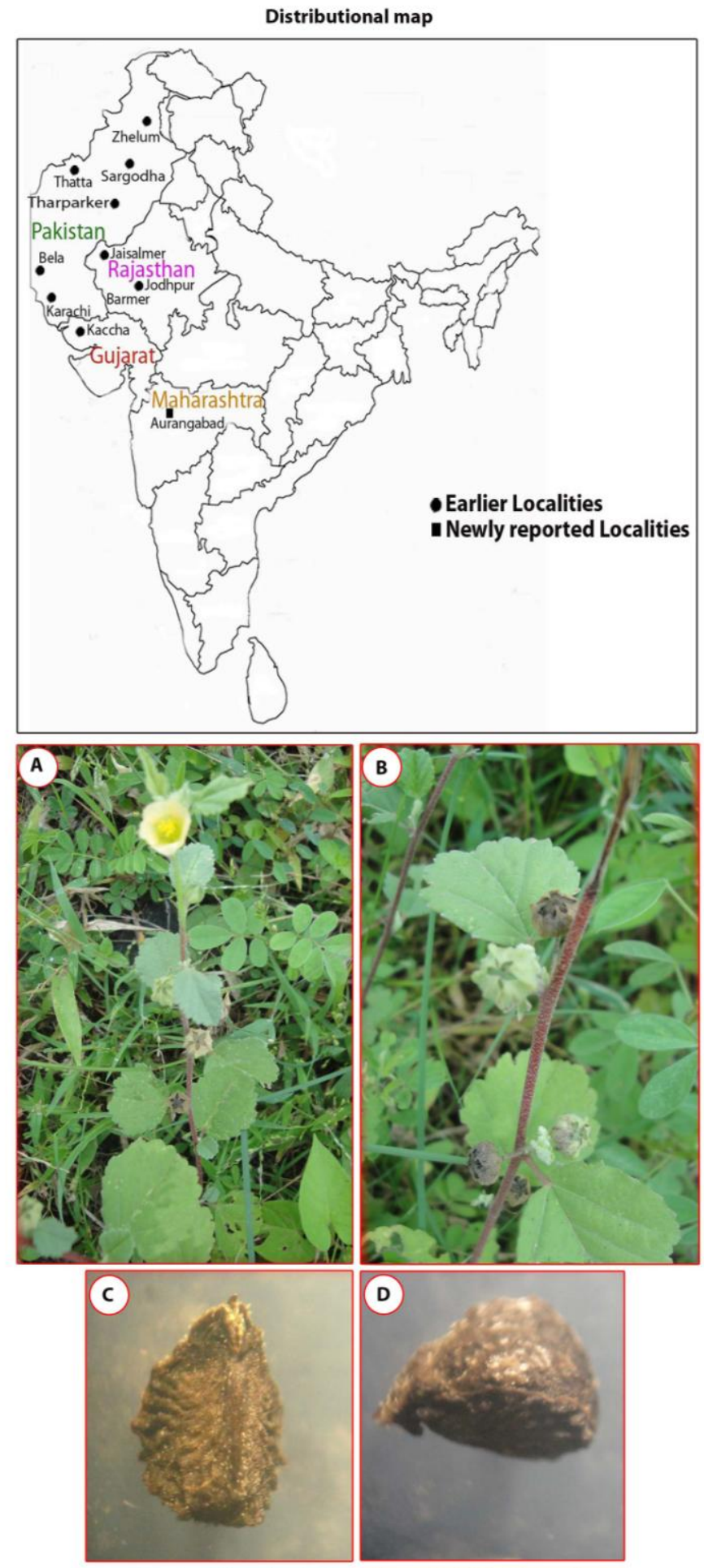

Sida tiagii Bhandari A. Flowering twig, B. Fruiting twig, C. Ventral view of seed and D. Dorsal view of Seed 


\section{Specimen examined}

Maharashtra State- Aurangabad Dist.- Near Soneri Mahal, University Campus, Aurangabad, S. S. Bhosale \& Arvind S. Dhabe 6201, Budhha caves Road, University Campus, Aurangabad S. S. Bhosale, 8549.

Medicinal uses: Sida tiagii Bhandari is a native taxon of the Indian and Pakistan desert area. Fruits used in folk medicine as a blood purifier, tonic and muscle strengthener (Bhandari, 1990; Tahir et al., 1996). Fruits are also used as antidepressant (Datusalia et al., 2009), acute and chronic hypoglycaemic (Datusalia et al., 2012) and antiinflammatory (Kumawat et al., 2012).

\section{References}

Bhandari, M.M. 1978. Flora of Indian Deserts, Scientific Publishers, Jodhpur, 74-75 pp.

Bhandari, M.M. 1990. Flora of Indian Deserts, MPS, Repros. Jodhpur, India, 43-53 pp.

Cooke, T. 1901. The Flora of the Presidency of Bombay, Vol.- 1 Botanical Survey of India, Calcutta.

Datusalia Ashok Kumar, Sharma Sunil, Kalra Pankaj and Samal Manas Kumar. 2009. Anti- depressant like Potential of Sida tiagii Bhandari Fruits in Mice. J. Health Sci., 55(4): 641-648 pp.

Datusalia Ashok Kumar, Dora Chander Prakash and Sharma Sunil. 2012. Acute and hypoglycaemic activity of Sida tiagii Fruits in N5- Streptozotocin Diabetic Rats. Acta Poloniae
Pharmaceutica- Drug Res., 69(4): 699$706 \mathrm{pp}$.

Joshi, P.N., E.B. Joshi and B.K. Joshi. 2012. Ecology and Conservation of threatened plants in Tapkeshwar Hill ranges in the Kachha island, Gujarat, India. $J$. Threatened Taxa, 4(2): 2390-2397.

Mabberly, D.J. 2008. A portable dictionary of the plants, their classification and uses $3^{\text {rd }}$ Ed., Cambridge University Press, Cambridge 661 pp.

Sharma, B.D. and Sanjappa, M. 1993. Flora of India, Vol.- 3, Botanical Survey of India, Calcutta, 257-394 pp.

Shetty, B.V., Singh, V. 1987. Flora of Rajasthan- Flora of India ser. 2, Botanical Survey of India Calcutta 133 pp.

Singh, N.P. and Karthikeyan, S. 2000. Flora of Maharashtra State Dicotyledones Vol., 1, Botanical Survey of India, Calcutta 324-329 pp.

Sivarajan, V.V. and Pradip, A.K. 1996. Malvaceae of Southern Peninsular India, A taxonomic monograph, Daya Publishing House, Trinagar, Delhi.

Survase, S.A. and A.S. Dhabe. 2013. "BAMU Herbarium and Herbarium Techniques", Bioinfolet, Vol. 10 (4A): 1177-1180.

Tahir Ali, R.D. and Qaiser, M. 1996. Hybridization in the Sida ovata complex (Malvaceae) 1 Evidence from Morphology, Chemistry and Cytology, Willdenowia, Bd. 25, H 2, 637-646 pp.

Tiwari, A.P. and Shukla, A.N. 2014. Sida tiagii Bhandari (Malvaceae)- A new addition to the flora of Madhya PradeshThe Indian Forester, Vol. 140(5): 549.

\section{How to cite this article:}

Santosh S. Bhosale, Nandkishor More, Brijkishor M. Rathor and Arvind S. Dhabe. 2016. Sida tiagii Bhandari (Malvaceae) - New Record to the Flora of Maharashtra State and It's Range Extension in Central and Western India. Int.J.Curr.Res.Aca.Rev.4(12): 178-181. doi: http://dx.doi.org/10.20546/ijcrar.2016.412.017 